smartcard, which will leave a clear audit trail and alert privacy officers to unusual requests. In public speeches, Richard Granger, Connecting for Health's chief executive, contrasts these procedures with the common current practice of leaving case notes unattended on reception desks and trolleys, with no record of who has viewed them. The comparison is disingenuous, however. Today, unscrupulous media organisations or private detectives would have to cultivate hundreds of NHS staff to have a good chance of getting access to any specific record. When records are available regardless of geography, they will need to find only one insider open to bribery or coercion. Even if the system guaranteed that the access would be detected, the damage might already have been done.

Although patient consent is the most controversial current issue, the use of universal, shared, electronic health records is likely to pose several challenges to medical practice. One is the need for better record keeping: doctors will have to enter data on the basis that they may be used by complete strangers to make critical decisions and viewed by the patients themselves (eventually, through the MyHealthspace system, to be launched on a revamped public website which will replace the current NHS Direct online). There is no room in this world for informal codes such as the apocryphal "normal for Norfolk."

Serious questions also remain unsettled about what information should go on the record, especially when it comes to a patient's social circumstances or information about third parties such as family members. One certainty is that the lifelong electronic health records created in partnership by doctors, other professions, and patients themselves will look very different from today's case notes.

\section{Adapting to change}

Four years after its conception, the NHS national programme for information technology still has the flexibility to accommodate changes in direction. A "refresh" of the programme's approach, expected shortly, will be presented largely as a response to the white paper Our Health, Our Care, Our Say, ${ }^{10}$ answering criticism that the national programme is poorly aligned with the government's NHS reforms. The refresh is likely to find ways of offering more choice in systems, while retaining the programme's national character. Richard Jeavons, the former health authority chief executive appointed last year to oversee the programme's implementation, says that in the new mixed health economy, connection to the national care records service will be more important than ever. "In the post reform world, it will be one of the few defining features of the NHS, along with treatment free at the point of care.'

The refresh will also need to find ways to inject some excitement into the programme. One possibility would be to create a few exemplar sites by quickly assembling components of electronic health records in the most promising sites. These might best be based on "natural communities" of a trust and general practices, rather than the local service provider boundaries, which were set to create billion pound contract opportunities rather than to reflect NHS data flows.

\section{Summary points}

The NHS information technology programme plans to transform medical records into a single resource shared by everyone involved in the process of care

The programme relies on connecting all care systems to a central record or spine

Delays in developing hospital information systems compliant with the spine have resulted in trusts having to adopt less functional systems

Public confidence in the security of the system will be essential to a useable spine

Four years into its story, it is still too early to predict whether the NHS programme will succeed or fail. The only guide is from history-that pioneers tend to overestimate the speed of technological change but underestimate its long term impact.

Contributors and sources: MC has written on healthcare informatics issues for journals, newspapers, and books for more than 15 years.

Competing interests: MC carried out a short assignment for the national programme for information technology in 2002 and has also written occasional articles and accepted paid speaking engagements for at least two contractors to the programme, BT and Microsoft.

1 Institute of Medicine. The computer based patient record. Washington, DC IoM, 1997:55.

2 Medix. Doctors' views about the national programme for IT. Jan 2006. www.medix-uk.com (accessed 5 Mar 2006).

Byrne L. Care records. House of Commons Official Report (Hansard): 2006 Feb 27:col 420w

4 Connecting for Health. Update on recent service issues, 16 Jan 2006. www.connectingforhealth.nhs.uk/news/update_service_issues (accessed 7 Mar 2006).

5 Anon. Engaging clinicians in IT- one step forward, two back. BMJ 2006;332:127.

6 Connecting for Health. Spending and progress update 2006. www.connectingforhealth.nhs.uk/news/news300106_spending (accessed 7 Mar 2006)

7 Connecting for Health. Response to child health interim application media coverage. www.connectingforhealth.nhs.uk/news/child_health_systems (accessed 8 Mar 2006).

8 NHS Information Authority. Share with care! People's views on consent and confidentiality of patient information. London: NHSIA, 2002

9 NHS. The care record guarantee. London: Connecting for Health, 2005. www.connectingforhealth.nhs.uk/all_images_and_docs/crbb/ www.connectingforhealth.nhs.uk/all_images
crs guarantee 2.pdf (accessed 7 Mar 2006).

10 Department of Health. Our health, our care, our say. London: DoH, 2006.

\section{Endpiece}

\section{Seeking enlightenment}

Those who seek should not stop seeking until they find. When they find, they will be disturbed. When they are disturbed, they will marvel, and will reign all over.

The Gospel of St Thomas

Submitted by Hazem Lashin, senior house officer, Robert Jones and Agnes Hunt Orthopaedic and District Hospital, Oswestry 